\title{
Dividends in specie: the granting of services or the right of use of assets
}

Michael Kok

BAcc (Hons), MAcc Taxation, Chartered Accountant (SA), Manager, PwC

\section{Rudie Nel}

BCom Accounting (Hons), MCom Taxation, Chartered Accountant (SA), Senior lecturer, School of Accountancy, Stellenbosch University

\begin{abstract}
SUMMARY
Dividends in specie are not defined by the Income Tax Act, which could result in uncertainty whether the granting of services or the right of use of assets to shareholders would be included in the ambit thereof. The uncertainty could result in the opportunity for dividends tax to be avoided and could also result in applicable deductions, claimed by the declaring company, not being recouped for tax purposes. This article investigated whether the granting of services or the right of use of assets to shareholders would constitute dividends in specie for purposes of the Income Tax Act by considering the South African perspective as well as guidance based on international practices. The article submits that a broad interpretation of the meaning of "dividend" and "in specie" in the Income Tax Act supports the granting of services or the right of use of assets as constituting dividends in specie. Furthermore, the context of the provisions contained in the Income Tax Act considered in this article, does not indicate findings contrary to the broad interpretation of the meaning of "dividend" and "in specie". The guidance obtained from investigating international practices of selected countries also indicated that the granting of services or the right of use of assets constitute dividends or shareholder benefits on which shareholders are taxed. This article concludes that the granting of services or the right of use of assets would constitute dividends in specie and that the specific guidance on the valuation of such benefits in terms of the Seventh Schedule to the Income Tax Act, could possibly be extended to the application in the context of dividends tax.
\end{abstract}

\section{Introduction}

A dividend in specie has been described as any dividend other than in the form of cash, and considered viable if declaring company is facing liquidity problems or the distribution of an asset instead of cash would make economic sense. ${ }^{2}$ Common forms of known dividends in specie

1 Stiglingh, Koekemoer, Van Heerden, Wilcocks, De Swardt \& Van der Zwan Silke: South African income tax (2018) 664.

2 Investopedia 2018 In specie available at https://www.investopedia.com/ terms/i/in_specie.asp (accessed 2018-01-31).

How to cite: Kok \& Nel 'Dividends in specie: the granting of services or the right of use of assets' 2019 De Jure Law Journal 221-241

http://dx.doi.org/10.17159/2225-7160/2019/v52a14 
include property, stock, scrip, and liquidating dividends. ${ }^{3}$ Companies could, however, also distribute other forms of property to their shareholders, including perks and benefits associated with their shareholding, which give them the right to such property, as well as discounts in respect of services. ${ }^{4}$ Dividends tax is levied in respect of dividends declared and paid by a company as defined in terms of section 1 of the Income Tax Act 58 of 1962 (hereafter referred to as the ITA) and section $64 \mathrm{E}(2)$ regulates the tax treatment for distributions other than in specie distributions and asset in specie distributions. Two types of dividends - cash and dividends in specie - are accordingly regulated by the ITA and are treated differently for purposes of dividends tax in terms of their valuation, timing, and liability for the payment of the dividends tax.

The fact that dividends in specie contemplated in section 64F of the ITA are not defined by the ITA gives rise to uncertainty as to what could possibly fall within its ambit. Ambiguity could also arise by the fact that the ITA refers to other terms which could also be conceived as dividends in specie, being "distribution in specie," 5 or "asset in specie". 6 Current guidance issued by the SARS in respect of dividends tax only distinguishes between financial instruments, movable or immovable property, and deemed dividends in respect of low-interest loans to certain shareholders. ${ }^{7}$ No current guidance is provided in respect of the granting of services or right of use of assets as dividends in specie. Under the dividends tax regime, reliance is placed on the wide definition of "dividend" to prevent avoidance of dividends tax, whereas, specific examples of deemed dividends were provided under the STC regime in order to prevent avoidance of dividends tax by structuring distributions in a manner other than a dividend. ${ }^{8}$ A company could therefore grant services or the right of use of assets to shareholders instead of a cash dividend under the dividends tax regime, in which case uncertainty could arise regarding whether or not these would constitute dividends in specie. The lack of guidance under the dividends tax regime could consequently result in incorrect interpretation and application in respect of dividends in specie. Uncertainty regarding aspects such as how the revenue authorities will treat a certain transaction, or how and by when the legislator will introduce new legislation, or amend existing legislation, may have a profound impact on the economy of a country. ${ }^{9}$ One of the canons of a good tax system is also that the tax system should contain

3 Accounting Tools 2018 Types of dividends in specie available at http:// www.accountingtools.com/types-of-dividends (accessed 2018-01-31).

4 The Share Centre 2018 Shareholder perks available at https://www.share. com/find-investments/shares/shareholder-perks/ (accessed 2018-01-31).

5 Para 75 of the Eighth Schedule.

6 S $10 B(2)(d)$ and S 64EA.

$7 \quad$ SARS Comprehensive guide to dividends tax (Issue 2) (2017) 62.

8 Mazansky "South Africa: New rules for tax on dividends (domestic and foreign) and other company distributions" 2012 Bulletin for International Taxation 172 .

$9 \quad$ Stiglingh et al supra $\mathrm{n} 1$ at 6 . 
elements of certainty. ${ }^{10}$ Attempting to investigate guidance to resolve uncertainty in interpretation could therefore contribute to the certainty of tax interpretation.

Apart from the preceding uncertainty, a practical tax issue in respect of the non-recoupment of deductions claimed by the declaring company is also conceived if services or the right of use of assets is granted to a shareholder. In the case of a distribution of an allowance asset, tax deductions or capital allowances for the company in respect of the asset distributed will be recouped in terms of section $8(4)(k)$ of the ITA on distribution of the asset as a dividend in specie. However, if a service or the right of use of an asset is granted as a dividend in specie, the declaring company could still claim deductions without any recoupment in terms of section $8(4)(\mathrm{k})$ or section $8(4)(\mathrm{a})$ on subsequent granting to the shareholder if no asset was distributed or amounts recouped. A deduction could thus be claimed on services or the right of use of an asset distributed to beneficial owners for something that in fact constitutes a dividend in specie. If services or the right of use of assets provided are not regarded as a "dividend" a natural person beneficial owners could benefit as no dividends tax is payable. Due to consecutive increases in the applicable tax rates of natural persons, the incentive for electing a distribution that does not constitute a dividend also increases. As shareholders could opt for the granting of services or the right of use of assets if not classified as a dividend, these methods could be applied to avoid dividends taxes and could also result in a non-recoupment of deductions claimed by the declaring company.

The objective of this article is to investigate whether the granting of services or the right of use of assets constitutes dividends in specie. This objective stems from a lack of specific guidance in respect of dividends in specie and the practical tax issue in respect of non-recoupment of deductions if a service or right of use is granted as dividends in specie. From a South African perspective an investigation into the purpose of the Seventh Schedule is also conducted for possible guidance on whether or not the intention of the legislator was to include granting of services or the right of use of assets within the ambit of a dividend in specie. The investigation into whether the granting of services or the right of use of assets constitutes dividends in specie could also benefit from consideration of international practices. The Secondary Tax on Companies (STC) regime was replaced with the dividends tax regime in order to align the tax on dividends with international practices as STC was unfamiliar to foreign investors. ${ }^{11}$ International experience is also considered an important aspect as it could offer lessons learned from those experiences. ${ }^{12}$ Based on the international practice of selected

10 Smith 1776 Wealth of nations.

11 Roeleveld "The road to dividend withholding tax in South African income tax law" 2015 Income tax in South Africa: The first 100 years (1914-2014) 120.

12 Arendse \& Stack "Investigating a new wealth tax in South Africa: Lessons from international experience" $2018 \mathrm{JEF} 1$. 
countries, guidance can be considered on whether or not the granting of services or the right of use of assets could constitute dividends for ITA purposes.

\section{South African perspective}

The South African perspective is investigated by considering the meaning of "dividend" and "in specie". For terms not defined in the ITA due consideration of interpretation approaches of fiscal legislation is warranted. ${ }^{13}$ The two main approaches that have been adopted by the South African courts are the literal approach and the purposive approach to interpretation. ${ }^{14}$ The literal approach is characterised by the strict and literal rule of interpretation of legislation by following the letter of the law, unless the legislation provides a specific definition thereof. According to the "golden rule" of interpretation the language in the document is to be given its grammatical and ordinary meaning, unless this would result in some absurdity, or some repugnancy or inconsistency with the rest of the instrument. ${ }^{15}$ In instances of uncertainty, ambiguity, or absurdity in the language used in legislation, the courts have departed from the strict literal approach and instead have sought to establish the so-called "intention of the legislature" referred to as the purposive approach, which takes into consideration the words used in legislation, viewed in their context, in order to interpret the purpose for which the provision was enacted. ${ }^{16}$ With the modern purposive approach to interpretation of documents from the outset considering the context and the language together, with neither predominating over the other. ${ }^{17}$ The purposive approach to interpretation therefore insists that context be considered in the first instance, especially in the case of general words, and not merely at some later stage when ambiguity might be thought to arise. ${ }^{18}$ When applying the purposive approach specific wording, together with the context in which it is used, should be used to interpret the legislation. ${ }^{19}$ If the ordinary meaning of a word therefore accords with the intention of the provision, further consideration is generally not required. ${ }^{20}$ The South African courts have also set guidelines that must be considered in order to apply the purposive approach recommending consideration of the precise wording of the provision, the context, and an overview of tax history of the provision when determining the purpose of the

13 Stiglingh et al supra $\mathrm{n} 1$ at 18.

14 De Koker \& Williams Silke on South African income tax (2017) para 25.1 A25.1D available at http://www.mylexisnexis.co.za (accessed 2018-02-28).

15 Coopers \& Lybrand v Bryant (1995) 3 SA 761 (A) 767.

16 De Koker \& Williams supra n 14 at para 25.1C.

17 Natal Municipal Joint Pension Fund v Endumeni (2012) 4 SA 593 (SCA) 16.

$18 K \&$ S Lake City Freighters Pty Ltd v Gordon \& Gotch Ltd (1985) 315.

19 De Koker \& Williams supra $\mathrm{n} 14$ at para 25.1D.

20 Goldswain "Hanged by a comma, groping in the dark and holy cows: Fingerprinting the judicial aids used in the interpretation of fiscal statutes" 2012 Southern African Business Review 37. 
provision. $^{21}$ The set guidelines is now applied in investigating the definition of "dividend" and meaning of dividend "in specie" in sections which follows.

\section{Definition of "dividend"}

The definition of a "dividend" underwent many amendments since 2007 to arrive at the definition as currently contained in the ITA. The current definition of "dividend" was introduced with effect from 1 January 2011 in anticipation of the dividends tax regime to be introduced. In 2008, company law in South Africa underwent a major transformation with the enactment of the new Companies Act, ${ }^{22}$ (the "Companies Act") which modernised company law in line with international and economic trends. An important change from the previous Companies Act, ${ }^{23}$ which had an effect on dividends, was the introduction of the solvency and liquidity test in place of the old capital maintenance rule. Provisions in the ITA directly or indirectly depend on company law definitions and principles, ${ }^{24}$ and as result amendments in the ITA was necessary to align the ITA with these definitions and principles as per company law. The Companies Act introduced the capital maintenance rules to ensure that shareholders would not withdraw company funds to the detriment of corporate creditors as issued share capital could not be return to shareholders and must be maintained to act as security for corporate creditors. ${ }^{25}$ The new rule, which replaced the capital maintenance rules, requires solvency and liquidity test in terms of which the directors of companies had to ensure that before a dividend is declared, the company satisfied the solvency (assets must be more than liabilities) and liquidity (have enough cash to settle short-term obligations) test before and after the distribution. The previous definition of a "dividend" in terms of the ITA incorporated the capital maintenance requirements in terms of the previous Companies Act and had to be amended with the introduction of the new Companies Act. The amended "dividend" definition removed reference to all elements of profits and reserves and regards any amount transferred or applied as a dividend, unless those dividends come from contributed tax capital. ${ }^{26}$ The new definition of "dividend" is also not concerned with the presence or absence of profits. ${ }^{27}$ Consequently, directors are able to pay out whatever they believed fit - provided the company met the solvency and liquidity requirements, ${ }^{28}$ without being

\footnotetext{
21 Goldswain supra n 20 at 37.

22 Companies Act 71 of 2008.

23 Companies Act 61 of 1973.

24 National Treasury Explanatory memorandum on the taxation laws amendment bill 2010 (2010) 37.

25 Van der Merwe "Reconsidering distributions: A critical analysis of the regulation of distributions to shareholders in the Companies Act of 2008" (2015) 11.

26 National Treasury supra n 24 at 37-38.

27 National Treasury supra n 24 at 24.

28 Edward Nathan Sonnenbergs Inc. "What constitutes a dividend" 2008 Integritax.
} 
concerned with the presence or absence of profits. With a change in wording generally reflecting a change in intention, ${ }^{29}$ the amended "dividend" definition could be indicative of a broad interpretation being intended by the legislator. The amended "dividend" is defined in section 1(1) of the ITA as:

- an amount

- to be transferred or applied

- by a company that is a resident

- for the benefit of or on behalf of any person and in respect of any share in that company

- by way of a distribution made by the company. ${ }^{30}$

For the granting of a service or the right of use of an asset to be included, it would first have to constitute an "amount". The word "amount" is used in the definition of "gross income" as defined in section 1 of the ITA and has been judicially considered in a number of cases and held to include not only money but the value of every form of property earned by the taxpayer, whether corporeal or incorporeal, which had a money value. ${ }^{31}$ If the term "amount" is given a broad meaning incorporeal property such as rights would also be included. In Cactus Investments (Pty) Ltd v CIR, ${ }^{32}$ the court held that in order to comprise an "amount", rights of a noncapital nature must be "capable of being valued in money". Similarly, in CIR $v$ People's Stores (Walvis Bay) (Pty) Ltd, ${ }^{33}$ the court held that in order to be included in gross income, an amount must be of such a nature that a monetary value can be attached thereto. In C:SARS $v$ Brummeria Renaissance (Pty) Ltd \& Others, ${ }^{34}$ it was held that it did not follow that if a receipt or accrual cannot be turned into money, it had no monetary value. The "turn into money" test was merely one of the tests for determining whether an accrual had monetary value. The court confirmed that the test was objective, and not subjective. In considering the context, the same broad meaning ascribed to the word "amount" must be given in the context of the definition of "dividend" in section 1(1) of the ITA. ${ }^{35}$ The granting of a service or the right of use of an asset would therefore constitute an "amount".

The amount should then be "transferred" or "applied" by a company that is a resident. The ordinary meaning of "transfer" is to convey or make over (title, right, or property) by deed or legal process and the ordinary meaning of "apply" to connect (something abstract) with (a person or thing) as its attribute or cause; to refer, ascribe, attribute. ${ }^{36}$ The

29 De Koker \& Williams supra n 14 at para 25.7I.

30 S 1(1) definition of "dividend" in Income Tax Act 58 of 1962

31 WH Lategan $v$ CIR 2 SATC 16 (1926) 19.

32 Cactus Investments (Pty) Ltd v CIR 61 SATC 43.

33 CIR v People's Stores (Walvis Bay) (Pty) Ltd 52 SATC 9

34 C:SARS v Brummeria Renaissance (Pty) Ltd \& Others 69 SATC 205.

35 SARS supra $\mathrm{n} 7$ at 24.

36 Oxford English Dictionary (2018). 
granting of services or the right of use of assets would adhere to this element of the definition as long as legal ownership of the right to the use of assets or services is transferred to the shareholder or is put to purpose or used by the shareholder. The meaning of "company that is a resident" is not submitted as contentious for purposes of this article. Furthermore, it would also be accepted that the granting of a service or the right of use of an asset would be in respect of a shares therefore not considered as specific focus for this article.

The final consideration is by way of a "distribution" made by the company. No definition of "distribution" is contained in the ITA, however, a common law dividend is provided by the SARS, ${ }^{37}$ as an example of a distribution. Distribute means to apportion, appropriate, allocate or apply towards, ${ }^{38}$ and as no longer dependent on profits will be a dividend if the company from a company law or accounting point of view is entitled to make the distribution to shareholders. ${ }^{39}$ The definition of "distribution" contained in the Companies Act is therefore considered for guidance on the meaning thereof. In terms of the Companies Act, a "distribution" includes the transfer by a company of money or other property of the company, other than its own shares, to or for the benefit of one or more holders of any of the shares of that company in the form of a dividend. The South African Companies Act and that of New Zealand have also been found to have similarities. ${ }^{40}$ The phrase "to or for" the benefit of one or more shareholder is also used in the definition of "distribution" as contained in the New Zealand Companies Act. When applying the interpretation by the New Zealand courts, ${ }^{41}$ in this regards any instance where a distribution causes wealth to flow from the company to the shareholder would be classified as a "distribution" in terms of the Companies Act. If the Companies Act's interpretation is applied to that used in the definition of "dividend" in the ITA, it would necessitate that any transfer of wealth from the company to the beneficial owner in respect of the beneficial owner's shareholding would be considered a dividend for tax purposes. On this premise the granting of services or the right of use of assets, wealth is transferred to the shareholder in respect of shareholding. The beneficial owner receives a benefit, either in the form of services or the use of company assets. The company, on the other hand, experiences a negative impact on its net value either due to costs associated with performing the services or allowing the beneficial owner to use company assets, or in the form of lost income (opportunity costs). The granting of a service or the right of use of an asset to a shareholder in respect of the shareholder's

37 SARS supra $\mathrm{n} 7$ at 27

38 CIR v Legal and General Assurance Society Ltd 1963 (3) SA 876 (A), 25 SATC 303, at 315.

39 Jutastat RS 23 Dividend (2018) Tax: Juta's Practice Collection Online (accessed 2019-04-26).

40 Jooste "Issues relating to the regulation of "distributions" by the 2008 Companies Act: Notes" 2009 South African Law Journal 635.

41 Re DML Resources Ltd (In Liquidation) (2004) 3 NZLR 490 (HC) at 505. 
shareholding could thus be considered a distribution for Companies Act purposes and by inference a dividend for ITA purposes.

Based on the above the definition of "dividend" does not contradict the interpretation that the intention of the legislator is to include other benefits within the ambit of the definition of "dividend" and is consistent with the modern purposive approach to interpret legislation. Considering the context of "dividend" as defined based on an overview of tax history of the provision also does not contradict the broad meaning submitted in terms of the wording and context. Owing to the fact that dividends "in specie" are treated differently for purposes of dividends tax in terms of their valuation, timing, and liability for the payment of the dividends tax consideration is also given to meaning of "in specie".

\section{Meaning of dividend "in specie"}

The ordinary meaning of "in specie" is "in its actual form" or "in kind". 42 The SARS also describes "in specie" as a distribution to shareholders in a form other than cash. ${ }^{43}$ The granting of services or the right of use of assets would be in the form other than cash and accordingly be regarded as dividends "in specie".

The ITA ${ }^{44}$ however, also refers to different terms which could also be conceived as dividends in specie, being "distribution in specie" or "asset in specie". The granting of services or the right of use of assets has been argued as a "distribution," ${ }^{45}$ consequently submitted as a distribution in specie. The main terms in the definition of "asset" in paragraph 1 of the Eighth Schedule are "property" and "a right" to such property. SARS describes "property" as anything that can be disposed of and turned into money. "A "A right" would include both personal rights (enforceable against a specific person). ${ }^{47}$ Granting of services is not submitted as an "asset" as such services are immediately consumed or utilised by the shareholder resulting in the personal rights obtained being exercised immediately. Granting the right of use of assets could result in an "asset" if the shareholder obtains right of use for a defined future period.

Based on the preceding the granting of services or the right of use of assets are submitted as dividends in specie contemplated in sections $10 B(2)(d)$ and 64EA of the ITA. Guidance based on the Seventh Schedule and international practices are subsequently considered for further guidance in support of the submission that the granting of services or the right of use of assets are dividends in specie.

42 Collins Dictionary (2018).

43 SARS What is a dividend in specie? (2018) available at http://www.sars.gov. za/FAQs/Pages/833.aspx (accessed 2018-01-31).

$44 \mathrm{~S} 10 \mathrm{~B}(2)(\mathrm{d}), \mathrm{s} 64 \mathrm{EA}$ and para 75 of the Eighth Schedule

45 Based on arguments submitted under 2.1 of this article.

46 SARS Comprehensive Guide to Capital Gains Tax (Issue 5) (2015) 39.

47 SARS supra $\mathrm{n} 45$ at 532. 


\section{Guidance based on the Seventh Schedule}

Benefits provided to employees by an employer are taxed in terms of the Seventh Schedule to the ITA. These benefits are taxed as a result of the employment relationship that exists between the employer and the employee. An investigation into the purpose of the Seventh Schedule is conducted in order to understand the reason for the implementation of the schedule, as well as whether it could provide guidance on whether or not the intention of the legislator could be to include granting of services or the right of use of assets within the ambit of a dividend in specie.

Fringe benefits provided by employers, such as housing and housing assistance schemes, travel allowances, and rental of movable and immovable property, became taxable in $1985,{ }^{48}$ and such inclusion broadened the tax base. The broadening of the tax base could be a useful tool for redistribution to the poorest by taxing the rich and a broad base also encourages lower tax rates which in turn will reduce tax evasion. ${ }^{49}$ These benefits were also often partially exempt from tax in order to compensate for the high marginal rate of tax during the period of the Margo Commission. Fringe benefits such as housing and holiday accommodation, company cars, and travel allowances became fully taxable in order to rectify a loophole that created a loss to the fiscus. ${ }^{50}$ Furthermore, anti-avoidance provisions were also introduced between 1997 and 1999 to prevent the abuse of company car schemes, travel allowances, and residential accommodation for employees. ${ }^{51}$ These reforms gradually started to decrease opportunities for tax avoidance in order to protect the tax base and to reduce loss to the fiscus. In the 2010 budget speech, the Minister of Finance, Pravin Gordhan, emphasised that the government would tighten fringe benefit rules to reduce tax avoidance and tax structuring. ${ }^{52}$ One of the main reasons for the implementation and further reforms to employees' tax in respect of fringe benefits, other than to broaden the tax base, was to combat special tax structures used to avoid tax.

The granting of services or the right of use of assets to shareholders as a dividend in specie could potentially not be taxed unless they fall within the ambit of the definition of a dividend as contained in section 1(1) of the ITA. These types of distributions would also not fall within the definition of a taxable benefit as defined in the Seventh Schedule to the ITA if no employment relationship exists. Thus, a potential structure

48 National Treasury Explanatory memorandum on the Income Tax Bill 1985 (1985) 3.

49 Ahmad \& Stern "Taxation for developing countries" in Chenery and Srinivasan Handbook of development economics (1989) 1065.

50 Katz Commission Interim report of the Commission of Inquiry into certain aspects of the tax structure of South Africa (1996) 33-34.

51 Nyamongo \& Schoeman "Tax reform and the progressivity of personal income tax in South Africa" 2007 South African Journal of Economics 480.

52 National Treasury Budget speech by the Minister of Finance, 22 February 2010 (2010) 15. 
exists for avoiding tax. Based on these findings, the intention of the legislator could be to include the granting of services or the right of use of assets to shareholders within the ambit of the definition of a dividend as contained in section 1(1) of the ITA. The taxing of fringe benefits was due to the benefits being granted in lieu of remuneration as structures to avoid tax. The same applies to the structuring of a distribution in a manner other than a dividend in order to avoid dividends tax, which in essence would be a distribution in lieu of cash or an asset that would have been taxed. The definition of "dividend" in section 1(1) of the ITA is interpreted broadly to prevent avoidance of dividends tax by structuring distributions in a manner other than dividends. ${ }^{53}$ Based on these findings, the benefits included in the ambit of "taxable benefits" in section 2 of the Seventh Schedule to the ITA could indicate what the legislator intended to fall within the ambit of dividends in specie for ITA purposes, which includes free or cheap services and the right of use of assets such as residential accommodation and motor vehicles.

The Seventh Schedule also contains specific guidance on the valuation of right of use of assets granted as fringe benefits. Paragraph 6 contains provisions for determining the cash equivalent of the right of use of any asset, other than residential accommodation or a motor vehicle. The value of the private or domestic use of such asset shall be either the rental amount paid by the employer if such asset is leased by the employer, or the value shall be determined as $15 \%$ per annum on the lesser of the cost or market value of the asset at the date of commencement of the period of use. ${ }^{54}$ If the asset is owned by the company before distribution, the value for dividends tax purposes could be calculated as $15 \%$ per annum of the market value at the date of distribution apportioned for the months used within a year of assessment. The taxable benefit specific to the right of use of a motor vehicle based on the "determined value" in relation to the motor vehicle. ${ }^{55}$ The general rule is that the value of private use is $3.5 \%$ of the "determined value" per month that the right of use was granted. Where the employer acquired the vehicle subject to a maintenance plan, the percentage is reduced to $3.25 \%$. If, however, the vehicle was acquired by the employer under an operating lease, the value of private use is determined to be the actual cost to the employer plus any fuel cost incurred. The provisions to determine the cash equivalent taxable benefit for the private use of residential accommodation stipulates that the value placed on the taxable benefit will be the "rental value" less any consideration paid by the employee to the employer. ${ }^{56}$ The "rental value" is determined by way of a formula; however, if the full ownership of the property is not vested in the employer, the "rental value" is the lower of the value per the formula or the expenditure

53 Mazansky "South Africa: New rules for tax on dividends (domestic and foreign) and other company distributions" 2012 Bulletin for International Taxation 172 .

54 Para 6(2) of the Seventh Schedule to the Income Tax Act 58 of 1962.

55 Para 7(1) of the Seventh Schedule to the Income Tax Act 58 of 1962.

56 Para 9(2) of the Seventh Schedule to the Income Tax Act 58 of 1962. 
incurred by the employer. The formula for the "rental value" is based on the remuneration proxy of an employee at $17 \%, 18 \%$, or $19 \%$ per annum and apportioned for the number of months the benefit is granted for during the year. The formula for determining the cash equivalent value of the right of use of residential accommodation will not be an appropriate way to determine the market value in context of dividend tax as the basis of the formula is a remuneration proxy as these fringe benefits are received in respect of employment, while for dividends tax the benefit is received due to shareholding.

Furthermore, the Seventh Schedule also contains specific guidance on the valuation of services granted as fringe benefits. Paragraph 10 contains provisions for determining the cash equivalent of services provided by employers to employees. ${ }^{57}$ The cash equivalent value of a taxable benefit derived from the rendering of a service to any employee shall be in the case of a travel facility granted by an employer, who is engaged in the business of conveying passengers by sea or air, the lowest fare payable by a passenger utilising such a facility less any consideration given by the employee, and in any other case the cost of such services to the employer in rendering such services or having such services rendered less any consideration given by the employee in respect of such services. ${ }^{58}$ Multiple circumstances are provided for where no value is placed on services provided by employers to employees, which include services used mainly for the purposes of the employer's business or for the improved performance of an employee's duties at work. Applying the guidance obtained from paragraph 10 to the distribution of services for dividends tax purposes, the value of travel services rendered would be the lowest fare payable by a passenger should an entity whose business is the conveying of passengers distribute such services to a shareholder, or in the case of any other services the cost to the entity in rendering such services or having such services rendered. For the purposes of section $64 \mathrm{E}$ the distribution of an asset in specie is deemed to be at market value and thus the market value of such services received by the shareholder would be a better option for the value of the deemed dividend. ${ }^{59}$ Thus the value would be the market-related selling price of such services and not only the cost for the entity in the case of services rendered by the entity. The cost of having services rendered would most likely be the market-related cost.

The aforementioned cash values in terms of the Seventh Schedule have been extended for application to another tax apart from normal tax, being Value-Added Tax. ${ }^{60}$ This article argues that the specific guidance on the valuation of services or right of use of assets in terms of the Seventh Schedule could also be extended to the application in the context of dividends tax. The international practice of selected countries is

57 Para 10 of the Seventh Schedule to the Income Tax Act 58 of 1962.

58 Para 10(1) of the Seventh Schedule to the Income Tax Act 58 of 1962.

$59 \mathrm{~S} 64 \mathrm{E}(3)$ of the Income Tax Act 58 of 1962.

60 S 10(13) of the Value-Added Tax Act 89 of 1991. 
further considered for international guidance on the tax of granting of services and the right of use of assets to shareholders.

\section{Guidance based on international practices}

The South African tax legislation has gone through many phases of tax reform; one of which started after the year 2000, which saw the adaptation of the tax system to conform to international tax law. ${ }^{61}$ Specifically, with regard to the taxing of distributions to shareholders, the STC regime was replaced with the dividends tax regime in order to align it with international practices. ${ }^{62}$ Investigating the tax implications of distributions by entities to shareholders in the context of international practices could provide guidance whether the granting of services or the right of use of assets could constitute dividends for ITA purposes. International practices could also provide guidance on the dividends tax treatment of the granting of services or the right of use of assets for purposes of dividends tax in the South African context. The countries and their respective taxation legislation used for this investigation are Canada, the UK, Australia, and the USA. The first three countries and South Africa are part of the Commonwealth, with the Commonwealth countries' legislation having common influences as these countries were once territories of the British Empire. ${ }^{63}$ Notwithstanding the fact that the USA does not form part of the Commonwealth countries, the inclusion of the USA as a country for investigation is considered as it provides practical guidance from a government that has paid attention to the granting of services and the right of use of company assets to shareholders. ${ }^{64}$ Canada, the UK, Australia and the USA were also four of the five countries included in the international comparison by National Treasury in revising the base for taxable distributions. ${ }^{65}$ It is recognised that transferring insights in respect of taxes between different countries could be a problematic endeavour as tax systems could differ significantly between countries. International experience could, however, still be considered as an important aspect as it could offer lessons learned from those experiences. ${ }^{66}$ The aim of this article is to consider international practices as a supplementary argument to the primary investigation performed in terms of the ITA in South Africa.

61 Nyamongo \& Schoeman "Tax reform and the progressivity of personal income tax in South Africa” 2007 South African Journal of Economics 480.

62 Roeleveld supra n 11 at 120.

63 Commonwealth Member countries (2018) available from http://the commonwealth.org/ member-countries (accessed 2018-06-30).

64 Kohla Dividend income from personal use of business assets 1974 American Bar Association Journal 1431.

65 National Treasury Dividends versus return of capital: Revising the base for taxable distributions (2008) 12-13.

66 Arendse \& Stack "Investigating a new wealth tax in South Africa: Lessons from international experience" 2018 JEF 1. 


\section{Canada}

Taxable dividend distributions made by companies to shareholders are included in the taxable income of the shareholder in terms of the Canadian Income Tax Act reads as follows:

"In computing the income of a taxpayer for a taxation year, there shall be included the total of the following amounts:

(a) the amount, if any, by which

(i) the total of all amounts, other than eligible dividends and amounts described in paragraph (c), (d) or (e), received by the taxpayer in the taxation year from corporations resident in Canada as, on account of, in lieu of payment of or in satisfaction of, taxable dividends." 67

The term "taxable dividend" is defined in the Canadian Income Tax Act R.S.C. of 1985 under section 89 is defined as a dividend other than certain exempt dividends that are listed in subsection (a) and (b) of the definition of a taxable dividend. ${ }^{68}$ This provides no insight into what would constitute a dividend other than the common law cash dividend. The Canadian Income Tax Act, however, contains section 15, which specifically deals with benefits conferred on shareholders. Section 15(1) states that if, at any time, a benefit is conferred by a corporation on a shareholder of the corporation or on a future shareholder of the corporation, the amount or value of the benefit is to be included in computing the income of the shareholder, unless the benefit is deemed to be a dividend in terms of section 84 . Section 84 deems the decrease of paid-up capital, distributions on winding-up, and the redemption of shares as dividends. Specific subsections exist for the forgiveness of debt, ${ }^{69}$ provision of shareholder debt, ${ }^{70}$ and automobile benefits. ${ }^{71}$ The value of the automobile benefit conferred on the shareholder is determined based on the provisions for taxable amounts to be included from employment. In terms of section 15(1.3), the value of all property and services conferred specifically includes all taxes paid for such property or services or should have been paid had the individual not been exempt from any such taxes. Section 15(2), relating to shareholder debt, is not applicable to non-residents, ordinary lending practices, when the loan is repaid within one year, and when the debt is provided to an employee in respect of employment.

Based on the above, section 15 has a broad scope in terms of what would be considered a benefit conferred on a shareholder. ${ }^{72}$ Even

67 S 82(1) of the Canadian Income Tax Act R.S.C. of 1985.

68 S 89 of the Canadian Income Tax Act R.S.C. of 1985.

69 S 15(1.2) of the Canadian Income Tax Act R.S.C. of 1985.

70 S 15(2) of the Canadian Income Tax Act R.S.C. of 1985.

71 S 15(5) of the Canadian Income Tax Act R.S.C. of 1985.

72 Mitchell "The 'dark path': subsection 15(1) of the Income Tax Act" 2012 Collins Barrow: Tax Alert 4 available at https://www.collinsbarrow.com/ uploads/docs/newsletter/national/archive/Tax \% 20Alert \% 20-\% 20Winter \% 202012.pdf (accessed 2018-06-30). 
though the Canadian Income Tax Act has a number of provisions to prevent shareholders from extracting wealth from a corporation without incurring a tax liability, section 15(1) provides a general provision to include benefits not covered by other provisions in the taxable income of a shareholder in the year the benefit is conferred. ${ }^{73}$ Thus, if shareholders extract wealth from a corporation other than through employment remuneration or investment income (common cash dividends and interest), all of which will be taxed under the provisions of section 15(1) which will include the value of the wealth extraction in the taxable income of the shareholder. Mitchell, ${ }^{74}$ identifies three important definitions that are relevant to the concept of a shareholder benefit, which are "shareholder", "benefit", and "value". A shareholder is defined as a person who is entitled to a dividend. The word "benefit" is not defined in the Canadian Income Tax Act, and a broad interpretation has been applied, which results in a broad range of transactions being regarded as taxable benefits interpreted to include, among others, the following:

- Personal use of corporate assets (e.g. real estate, aircraft, horses);

- Corporate payment of personal expenses;

- Gifts to shareholders' relatives;

- Inadequate consideration of sale of corporate assets; and

- Travel reward points. ${ }^{75}$

The "value" of the benefit is considered by the Canadian Revenue Authority to be the fair market value of that benefit. ${ }^{76}$ In Youngman $v$ The Queen, ${ }^{77}$ it was held that in circumstances where the fair market value rent for the property is not appropriate or cannot be determined, the amount or value of the benefit will generally be determined by multiplying a normal rate of return with the greater of the cost or fair market value of the property. This will be the case when, for example, an asset is built specifically for the shareholder, as not merely the right to use the asset is conferred but also the right to use an asset built specifically for the shareholder. The Canadian courts have thus held that in circumstances where the fair market value rent is not appropriate, the value of the benefit would be the income the corporation would have earned had the capital been productively employed. Shareholder benefits that trigger section 15 will be taxed at the individual's marginal rate of tax due to the value of the benefit being included in the taxable income of the individual receiving the benefit. The amount is also not deductible by the corporation. ${ }^{78}$ Section 15 (1) will not apply to bona fide business

73 Canadian Income Tax Act R.S.C. of 1985

74 Mitchell 2012 Collins Barrow: Tax Alert 5.

75 Mitchell 2012 Collins Barrow: Tax Alert 5.

76 Mitchell supra $\mathrm{n} 75$ at 5 .

77 Youngman $v$ The Queen, 90 DTC 6322, (1990) 2 C.T.C. 10

78 Hennessey "Another reason to avoid shareholder benefits" 2016 CTF 1 available at https://www.ctf.ca/ctfweb/EN/ Newsletters/Canadian_Tax_ Focus/2016/1/160103.aspx (accessed 2018-04-30). 
transactions or if the benefit arose due to employment and not due to shareholding.

In the South African context, the definition of a dividend also refers to any amount for the benefit of any person that is transferred or applied. It is submitted that based on the taxing of shareholder benefits by the Canadian Income Tax Act, it should also be included in the South African context due to the use of "benefit" in the dividend definition. Guidance from the Canadian Income Tax Act indicates that the granting of services and the right of use of assets would be included within the ambit of the dividend definition in the ITA. A broad interpretation is applied to the word "benefit" in the Canadian Income Tax Act and academics have interpreted "benefit" to include the personal use of corporate assets. It is submitted that this same broad interpretation should be applied in the South African context. Section 15(1) of the Canadian Income Tax Act provides for all other cases where wealth is extracted from a corporation other than through remuneration or investment income. South Africa does not contain such a general provision and it is submitted that the dividend definition contained in the ITA has a broad interpretation in order to also include wealth extraction from a corporation other than through remuneration or investment income.

Guidance obtained from the Canadian courts on how to determine the fair market value of the benefit indicates that it would be the fair market value rent for that benefit. In cases where the fair market value rent is not appropriate or cannot be determined, the value of the benefit is the income the corporation would have earned had the capital been productively employed. These principles could be applied in the South African context to value the granting of services or the right of use of asset for dividends tax purposes.

\section{United Kingdom (UK)}

Taxing provisions for dividends and company distributions are contained in sections 382 to 401 of the Income Tax (Trading and Other Income) Act of 2005 . $^{79}$ Within these sections, reference is made to dividends and other distributions. No definition of "distribution" is contained within the Income Tax (Trading and Other Income) Act of 2005, and the definition of "distribution" for purposes of this act is contained within the Corporation Tax Act of 2010. ${ }^{80}$ Section 1000(1) of the Corporation Tax Act of 2010 defines the meaning of "distribution" and includes any dividend or any other distribution out of the assets of the company. Also included are any securities issued by the company or any interest or other distribution out of the assets of the company, whether in cash or not. Section 1000(2) of

79 UK Income Tax (Trading and Other Income) Act of 2005.

80 Her Majesty's Revenue and Customs (HMRC) 2015 Corporation tax, income tax and capital gains tax: Company distributions available at https://www.gov. uk/government/publications/corporation-tax-income-tax-and-capital-gainstax-company-distributions/corporation-tax-income-tax-and-capital-gainstax-company-distributions (accessed 2018-06-30) 
the Corporation Tax Act of 2010 also includes in the definition of "distribution" any amount treated as a distribution in terms of section $1064^{81}$

Section 1064 regards certain expenses of close corporations as distributions and applies to expenses incurred by a close corporation on behalf of any participator in the close corporation. A participator is defined as "a person having a share or interest in the capital or income of the company". Section 1064(2) states that:

"where a close company incurs expense in or in connection with the provision for any participator of living or other accommodation, of entertainment, of domestic or other services, or of other benefits or facilities of whatever nature, the company shall be treated as making a distribution to the participator of an amount equal to so much of that expense as is not made good to the company by the participator". 82

When comparing this to the dividend definition in the ITA of South Africa, the words "applied" and "on behalf of" are also used, which would include expenses paid by a company on behalf of a person in respect of a share. Guidance from the UK would indicate that in the South African context, any expenses paid for on behalf of a person in respect of a share would be interpreted as being included in the ambit of a dividend. The granting of services and the right of use of assets would thus fall within the ambit of a dividend if the company pays for the granting of services or the right of use of assets on behalf of a person in respect of a share. As the ITA provisions in South Africa also include distributions on behalf of any person in respect of any share, no further guidance is obtained from the UK practice.

\section{Australia}

Australian taxation legislation is contained in different acts. The most relevant for purposes of this discussion are the Income Tax Assessment Act of 1936, the Taxation Administration Act of 1953, and the Income Tax Assessment Act of 1997. The main sections in the Australian Income Tax Assessment Act of 1936 that contain provisions for the taxing of dividends are section 44 for resident shareholders and section $128 \mathrm{~B}$ for withholding tax on non-resident shareholders. In terms of section 44(1), dividends are paid to shareholders by the company from profits derived from any source. ${ }^{83}$ Section $44(1 \mathrm{~A})$ states that for purposes of the Income Tax Assessment Act of 1936, in terms of dividends paid out of an amount other than profits, the dividends are deemed paid out of profits. ${ }^{84}$ Section 44 also refers to dividends being in the form of money or other property. The definition of "property" can be found in section 343 of this Act, which states that property includes money. This provides no

81 UK Income Tax (Trading and Other Income) Act of 2005.

82 S 1064(2) of the UK Income Tax (Trading and Other Income) Act of 2005.

83 S 44(1) of the Australian Income Tax Assessment Act of 1936.

84 S 44(1) of the Australian Income Tax Assessment Act of 1936. 
guidance in terms of what would be considered property distributed for purposes of dividends tax. The definition of a dividend found in section 995.1 of the Income Tax Assessment Act of 1997 states that "dividend" has the meaning given by section 6(1) of the Income Tax Assessment Act of 1936. A dividend would therefore include any distribution made by a company to any of its shareholders, whether in money or other property. ${ }^{85}$ No particular guidance is obtained from these sections on what would constitute "other property".

Further guidance is sought from the provisions that regulate distributions to non-resident shareholders. The Taxation Administration Act of 1953 regulates the withholding arrangements for dividends to nonresidents, which are found in divisions 12 and 14 of this Act. Division 14: Non-cash benefits and accruing gains, for which amounts must be paid to the commissioner, has the objective of placing entities that provide non-cash benefits, and entities that receive them, in a position similar to their position under division 12. Division 14 thus treats the benefit as if a payment of money had been made instead of a non-cash benefit being provided and included in division 12 are the withholding tax provisions for dividends paid to non-residents. ${ }^{86}$ Thus, if an entity provides noncash benefits to non-residents, it will be treated in the same manner as if it had been a cash dividend. Division 14 prevents entities from avoiding their obligation to withhold tax on distributions by providing non-cash benefits as an alternative. Subdivision 14-10 states that if an entity receives a dividend in the form of a non-cash benefit, tax must be withheld and paid over to the commissioner. The meaning of "entity" is found in section 960-100 of the Income Tax Assessment Act of 1997, which includes individuals and corporates. The specific inclusion of division 14 in the Taxation Administration Act of 1953 indicates that the legislator's intention was that the meaning of "other property" as contained in the definition of "dividend" would include non-cash benefits. ${ }^{87}$ The Income Tax Assessment Act of 1997 defines non-cash benefits in terms of section 995.1 as "property or services in any form except money".

Further guidance on the meaning of non-cash benefits is obtained from the provisions that regulate non-cash business benefits, which are found in section 21 A of the Income Tax Assessment Act of 1936. Section $21 \mathrm{~A}$ states that for the purpose of the act, if a non-cash business benefit is not convertible to cash, it is deemed as if it were convertible to cash, and any restrictions or prevention of converting the benefit to cash will be disregarded when valuing the benefit. ${ }^{88}$ The benefit shall be brought into account at its arm's-length value reduced by any contribution paid by the recipient for the benefit. Arm's-length value is defined in section $21 \mathrm{~A}(5)$ as:

85 S 6(1)(a) of the Australian Income Tax Assessment Act of 1997.

86 Australian Taxation Administration Act of 1953.

87 Division 14 of the Australian Taxation Administration Act of 1953.

88 S 21A(1) of the Australian Income Tax Assessment Act of 1936. 
"the amount that the recipient could reasonably be expected to have been required to pay to obtain the benefit from the provider under a transaction where the parties to the transaction are dealing with each other at arm's length in relation to the transaction" 89

In terms of section $21 \mathrm{~A}$, non-cash business benefits are non-cash benefits provided in respect of a business relationship and include property and services. Services are further defined in the Income Tax Assessment Act of 1936 as "any benefit, right (including the right in relation to, and an interest in, real or personal property), privilege or facility and, without limiting the generality of the foregoing, includes a right, benefit, privilege, service or facility that is, or is to be, provided" in respect of a business relationship. 90 The meaning of a "non-cash benefit" in the provisions for dividends tax is ascribed to the term "other property" due to the reference to non-cash benefits in the administration of the withholding tax on dividends. Thus, for purposes of the Australian tax system, a "dividend" would include, among others, the granting of services or the right of use of assets. When considering the timing of when such a benefit is obtained and tax should be levied, Taxation Ruling $96 / 6,{ }^{91}$ states that the facts of each case must be considered, but guidance is given that this would most likely be when there are no more steps required in order to become entitled to the benefit.

The definition of "dividend" in the ITA of South Africa refers to any "amount" being transferred or applied, with "amount" including not only cash but all forms of property. Applying the guidance from the Australian Income Tax acts' regulation of distributions indicates that property includes non-cash benefits, which in turn include services and rights. The granting of services or the right of use of assets could thus constitute dividends in specie. Guidance on valuing the benefit indicates that the arm's-length value is the most appropriate value, similar to the market value, to be placed on dividends in specie in section $64 \mathrm{E}(3)$ of the ITA of South Africa.

\section{United States of America (USA)}

Provisions regulating distributions by corporations are found in sections 301 to 318 of the Title 26 Internal Revenue Code (IRC) of the US Code. ${ }^{92}$ "Dividend" is defined under section 316(a) as "any distribution of property made by a corporation to its shareholders". "Property" is defined under section 317(a) as "money, securities, and any other property except that such term does not include stock in the corporation

$89 \mathrm{~S} 21 \mathrm{~A}(5)$ of the Australian Income Tax Assessment Act of 1936.

$90 \mathrm{~S} 21 \mathrm{~A}(5)$ of the Australian Income Tax Assessment Act of 1936.

91 Commonwealth of Australia 1996 Taxation Ruling 96/6 available at https:// www.ato.gov.au/law/view/document?DocID = TXR/TR966/NAT/ATO/00001 \& PiT $=99991231235958$ (accessed 2018-06-30) .

92 Legal Information Institute (undated) Title 26 of the Internal Revenue code and federal regulations available at https://www.law.cornell.edu/uscode/text/ 26 (accessed 2018-06-30). 
making the distribution (or rights to acquire such stock)". 93 The value attributable to a dividend of property is the amount of money received if received in cash, otherwise the fair market value if other property is received. ${ }^{94}$

The Code of Federal Regulations (CFR) is a codification of general and permanent rules and regulations published in the Federal Register by agencies of the federal government of the USA. Agencies such as the Internal Revenue Service (IRS) promulgate regulations and rules specific to their subject area, which are divided into 50 broad subject areas that are updated on a regular basis. CFR Title 26 contains the regulations and rules published for internal revenue in section 1.301-1(j) which states, in part, that if property is transferred by a corporation to a shareholder who is not a corporation, for an amount that is less than its fair market value in a sale or exchange, such a shareholder shall be treated as having received a distribution to which section 301 of the $I R C$ Code applies. ${ }^{95}$ In such a case, the amount of the distribution shall be the difference between the amount paid by the shareholder for the property and its fair market value. The provision of services and the use of corporate-owned property have been held to be "property" for purposes of section 301.96 Furthermore, it was also held by the US courts that the distribution of corporate earnings to or for the benefit of shareholders may constitute a dividend to the shareholder, notwithstanding that the formalities of a dividend declaration are not observed, not recorded in the accounting records of the entity, or even if some of the shareholders do not participate in the benefit distributed. ${ }^{97}$

Guidance from Title 26 IRC dividends sections indicates that property also constitutes dividends, and property in turn includes services and the use of corporate-owned property. This interpretation could be of assistance in interpreting what could be included in the ambit of "amount" for ITA purposes as "amount" includes property. Based on this guidance, the granting of services or the right of use of assets could be interpreted as being included in the ambit of the definition of "dividend".

\section{Conclusion}

The broad interpretation of the meaning of "dividend" and "in specie" in the ITA supports the granting of services or the right of use of assets as constituting dividends in specie. Furthermore, the context of the provisions contained in the ITA considered in this article does not indicate findings contrary to the broad interpretation of the meaning of "dividend" and "in specie" in the ITA. The definition of "dividend" has

\footnotetext{
93 S 317 (a) of Title 26 Internal Revenue Code (IRC) of the US Code.

94 S $301(b)(1)$.

95 Title 26 Internal Revenue Code (IRC) of the US Code.

96 Ireland $v$ United States 621 F.2d 731, 735 (5th Cir. 1980).

97 Paramount-Richards Theatres $v$ Commissioner 153 F.2d 602, 604 (5th Cir. 1946).
} 
been amended as result of amendments to the Companies Act and the removal of the profits as requirement in both Acts could be indicative of a broad interpretation being intended by legislator. The use of "any amount" in the dividend definition furthermore supports a broad interpretation in respect of which this article submits that the granting of services or right of use of assets should also be included within this broad interpretation. Ambiguity could result from the fact that the ITA refers to other terms which could also be conceived as dividends in specie, being "distribution in specie", 98 or "asset in specie", 99 and in this regards further guidance from government could assist in clarifying whether these terms should bear the same meaning as other references to dividends in specie.

An investigation into the purpose of the Seventh Schedule indicated that the aim of the introduction of the Seventh Schedule was to eliminate loopholes as employees structured their remuneration packages to avoid income tax by including non-taxable fringe benefits. In the context of dividends tax, this article posits that the granting of services or the right of use of assets in respect of shareholding could also be employed to avoid dividends tax implications if uncertainty regarding classification as dividends in specie is not clarified. The Seventh Schedule also provides specific guidance on valuing services, the right of use of motor vehicles, residential property, and other assets granted as benefits from a South African perspective. This article posits that the provision for valuing fringe benefits in terms of the Seventh Schedule could also be considered in valuing such benefits granted to shareholders for dividends tax purposes.

The findings from investigating international practices indicated that the granting of services or the right of use of assets constitutes dividends in Australia, the UK, and the USA, while in Canada these are taxed as shareholder benefits included in the shareholders' taxable income. Canadian legislation includes provisions for tax benefits received by shareholders, which specifically include provisions for taxing the use of a motor vehicle for private purposes by a shareholder. The value of the motor vehicle benefit conferred on the shareholder is determined based on the provisions for taxable amounts to be included from employment. From the Canadian context, a link is made between dividends tax and employees' tax for determining the value of the motor vehicle benefit. This could indicate that from a South African perspective, guidance can be obtained for the value to be attributed for tax purposes to the granting of services or the right of use of assets from the Seventh Schedule. Canadian academics have interpreted "shareholder benefits" broadly and have included the right of use of various corporate assets and gifts to shareholders or their relatives. The British legislation deems certain expenses paid by an entity on behalf of a shareholder as a distribution for dividends tax purposes. The Australian legislation deems non-cash

98 Para 75 of the Eighth Schedule

$99 \mathrm{~S} 10 \mathrm{~B}(2)(\mathrm{d})$ and Section 64EA 
benefits (a right, benefit, privilege, service, or facility) received by a shareholder to be treated the same as if it were received in cash. This is because it is submitted that the legislator's intention is that the meaning of "other property" as contained in the definition of "dividend" would include non-cash benefits. In the USA, distributions of other property, such as services and the private use of corporate assets, referred to as constructive dividends, have received much attention from the IRS, yet no official provisions or policies for determining the value of the deemed dividends exist. ${ }^{100}$ Dividends include the distribution of property and the US courts have held that property includes the provision of services and the use of corporate-owned property. Based on international practices, the granting of a service or the right of use of an asset to a shareholder will be taxed as dividends. International guidance was also obtained on how to value the right of the benefit received by the shareholder, taking into consideration the specific facts of each case.

Although a taxpayer has the right to arrange affairs in such a manner as to obtain the most favourable tax position, ${ }^{101}$ any disguised transaction surrounding a transaction will be ignored and the commercial sense of the transaction will be examined in order to ascertain its real substance and purpose. ${ }^{102}$ When applied in the context of dividends, it would mean that if the true purpose of a benefit granted to a shareholder was to extract wealth in lieu of cash dividends from an entity, then the substance of the transaction is a dividend and accordingly should be considered for dividends tax purposes. From a South African perspective reliance on the broad "dividend" definition resulted in a lack of specific guidance in respect of dividends in specie and the practical tax issue in respect of non-recoupment of deductions if a service or right of use is granted as dividends in specie as highlighted by this article. Due to the fact that dividends and dividends in specie are treated differently for purposes of dividends tax in terms of their valuation, timing, and liability for the payment of the dividends tax further specific guidance from government could be warranted.

100 Kohla supra $\mathrm{n} 57$ at 1431

101 Erf 3183/1 Ladysmith (Pty) Ltd and Another v CIR (1996 A) 58 SATC 229.

102 C:SARS $v$ NWK Ltd (2011) 73 SATC 55. 